IZA DP No. 8689

Expropriation with Hukou Change:

Evidence from a Quasi-Natural Experiment

Mehtap Akgüç

Xingfei Liu

Massimiliano Tani

December 2014 


\title{
Expropriation with Hukou Change: Evidence from a Quasi-Natural Experiment
}

\author{
Mehtap Akgüç \\ Centre for European Policy Studies (CEPS) and IZA \\ Xingfei Liu \\ $I Z A$ \\ Massimiliano Tani \\ University of New South Wales and IZA
}

Discussion Paper No. 8689

December 2014

\author{
IZA \\ P.O. Box 7240 \\ 53072 Bonn \\ Germany \\ Phone: +49-228-3894-0 \\ Fax: +49-228-3894-180 \\ E-mail: iza@iza.org
}

\begin{abstract}
Any opinions expressed here are those of the author(s) and not those of IZA. Research published in this series may include views on policy, but the institute itself takes no institutional policy positions. The IZA research network is committed to the IZA Guiding Principles of Research Integrity.

The Institute for the Study of Labor (IZA) in Bonn is a local and virtual international research center and a place of communication between science, politics and business. IZA is an independent nonprofit organization supported by Deutsche Post Foundation. The center is associated with the University of Bonn and offers a stimulating research environment through its international network, workshops and conferences, data service, project support, research visits and doctoral program. IZA engages in (i) original and internationally competitive research in all fields of labor economics, (ii) development of policy concepts, and (iii) dissemination of research results and concepts to the interested public.
\end{abstract}

IZA Discussion Papers often represent preliminary work and are circulated to encourage discussion. Citation of such a paper should account for its provisional character. A revised version may be available directly from the author. 
IZA Discussion Paper No. 8689

December 2014

\section{ABSTRACT \\ Expropriation with Hukou Change: Evidence from a Quasi-Natural Experiment}

We study the labor market outcomes of males aged 18-60 obtaining an urban hukou as a result of land expropriation across a number of provinces in China. Using 2008 and 2009 RUMiC data pooling urban, rural and migrant samples, we find that those obtaining an urban hukou have better labour market outcomes than rural stayers and migrants, and close the gap vis-à-vis native urbanites. We also find that children of families experiencing a hukou change due to expropriation have similar investment in human capital as the children of native urban hukou holders. The results confirm the hukou status as a strong economic determinant of labor market outcomes and as a source of inequality. Differences in educational investment, regardless of the differences in parental background, appear however to disappear for the children of families experiencing expropriation, suggesting that leveling the hukou status amongst children in an urban area may be a first step towards reducing intergenerational inequality.

JEL Classification: D19, H13, J18, O12, O43, R20

Keywords: expropriation, China, labour markets, economic reform, quasi-experiment

Corresponding author:

Xingfei Liu

IZA

Schaumburg-Lippe-Str. 5-9

53113 Bonn

Germany

E-mail: liu@iza.org

\footnotetext{
* We are grateful to Núria Rodríguez-Planas, Arnaud Chevalier as well as participants to seminars at Monash University and IIT (Kanpur) and the 6th IZA/CIER Annual Workshop on Research in Labor Economics.
} 


\section{Introduction}

The economic development of China provides an opportunity to study the behaviour of individuals facing a wider set of labour market choices, as the country transforms from a rural, centralised state to an urban, market-oriented economy. The emergence of local urban markets in which workers and firms interact is of particular interest, as the reforms introduced since 1978 have eased restrictions on the private ownership of enterprises but have maintained a residence system (Hukou) which grants individual holders different rights on the public goods and services available in the geographic area where they live. These rights include employment in local state-owned enterprises and access to public welfare, such as subsidised housing and, importantly, access to subsidised education for children.

The hukou system was introduced in 1958 as one of the measures devised by the regime to foster its Big Push industrialisation strategy. To fast accumulate capital in the newly nationalised manufacturing sector, which was mostly located in cities, the government collectivised the rural population and production to generate food and raw material as dictated. It then elected to become the sole and mandatory buyer and seller of rural produce to set the prices at which agricultural inputs were sold. It finally registered since 1955 each person as rural or urban preventing rural hukou-holders, since 1958, to become urban hukouholders without the prior approval of the places of destination. These measures capped the annual quota of conversions to about $0.15 \%-0.2 \%$ of the non-agricultural population (Chan, 2009).

Although economic reforms post-1978 have enabled people to relocate from rural to urban areas, the hukou system still prevents rural-urban migrants to enjoy the same rights and privileges as their urban counterparts, or doing so at the same price. This, in turn, has established not only a dual labour market in urban China, but also a persistent source of inequality affecting both those who work and their families.

Labour market analyses of the hukou system predominantly focus on rural-urban workers only, confirming their lesser labour market outcomes vis-à-vis the urbanites. Little research seems to exist about the effects of the hukou system on key economic outcomes of household members. Yet, once a family forms, labour supply decisions as well as educational choices for under-age children are likely to be taken in a household's context, aggregating the utilities of individual members.

Thanks to a new database, the Longitudinal Survey on Rural Urban Migration in China (RUMiC - Akgüç, Giulietti, and Zimmermann, 2014), we are able to estimate the 
effects of the hukou status on labour market and educational decisions of Chinese households exploiting a unique exogenous random shock: the expropriation of land and the change of hukou status into urban hukou. Since the Chinese population is classified as rural or urban on the basis of residence in 1958, this particular form of expropriation can be viewed as a quasinatural experiment. As a result, it is possible to give a causal interpretation to its effects.

Our attention is restricted to the labour market outcomes of working-age male household heads and their female spouses at the time of survey (2008 and 2009), and to the years of education completed by their children in the 10-20 age group. This latter restriction enables us to capture their choice of undertaking mandatory and non-mandatory preuniversity schooling following expropriation. Children holding an urban hukou have easier access to urban schooling and enjoy subsidised prices.

To compensate for the lack of a natural counterfactual, we carry out the analysis using five reference groups. These groups differ in changing/non-changing either residence or hukou status, or both: we hence measure the labour market and educational outcomes from a change in hukou status following expropriation relative to (i) non-changers of both hukou and residence (urbanites and rural stayers), (ii) changers of both hukou and residence (those obtaining an urban hukou because of their skills), and (iii) hukou non-changers but residence changers (migrants).

The results support that receiving an urban hukou as a result of expropriation improves considerably the labour market outcomes of those affected relative to those of migrants and rural stayers. Such improvement is however not enough to close the gap with the outcomes enjoyed by native urbanites and those receiving an urban hukou as a result of their high skills and education.

We also find that the children of the expropriated-urban hukou-receivers complete as many years of education as the children of the two urban reference groups, which are substantially more than those completed by the children of migrants and rural stayers. This result implies that having similar rights to access urban schools may favour an intergenerational convergence in human capital, up to age 20, amongst children of families with vastly different backgrounds.

The rest of the paper is organised as follows. Section 2 discusses previous literature and outlines the mechanics of land expropriation. Section 3 presents the data and variables used. The discussion of methodology and results is in Section 4. Section 5 concludes the paper. 


\section{Literature}

Very little work has analysed the economic effects of a change of hukou following land expropriation, though large and separate literatures study the economic impact of holding a rural hukou in an urban area, and the process and consequences of land expropriation in China. This lack of research is most likely explained by the fact that expropriation per se does not entitle to a change in hukou status: the construction of a new railway or motorway through some rural land is unlikely to result in the expropriated receiving urban hukou rights from the nearest city. Expropriation with 'helicopter legal rights' occurs when a city expands, taking over its rural countryside to relocate people because of expanding economic activities, like the development of a new airport, housing estate or industrial area. The exact motives and mechanics for expropriation with a change in hukou type have been neither homogeneous throughout China nor consistent over time within the same area (Ho and Lin, 2003).

The expropriation discussed in this paper occurs when the state expropriates rural land owned by a collective and keeps it under its management to assigning it as urban land by either allocation or conveyance ${ }^{1}$. Despite the largely unanswered challenge of understanding the exact circumstances under which the combination expropriation-hukou change occurs, we exploit its occurrence as a quasi-natural experiment to provide a causal explanation of its economic effects. Our paper therefore provides an estimate of the economic effects of holding a rural vis-à-vis an urban hukou, connecting and complementing two streams of research.

The first stream is the literature studying the inequality between urban and rural hukou holders which characterises China's urban population. This literature has documented the conditions and labour market outcomes of migrants who endure barriers to the welfare support available to city residents. Rural hukou holders living in a city have no effective

\footnotetext{
1 A brief history helps understanding the incentives behind expropriation. Private land ownership in China effectively stops in 1956 (Ho and Lin, 2003). From then onwards, land ownership and its management have been in the hands of either state, which owns all urban land and some countryside land (e.g. forests), or communes, which own most agricultural land. In 1978, land reforms allowed Chinese farmers to lease agricultural land from their communes for a fee and keep the surplus, and to engage migrant workers from other rural areas to attend their fields while the lessors migrated to the cities to enjoy higher wages from urban jobs. The ensuing increases in productivity fuelled demand for consumption, and contributed to reform permissible forms of capital ownership. The increasing number of new enterprises prompted cities to expand their boundaries, via expropriation, to accommodate an expanded demand for commercial as well as residential land. In 1988 China allowed the commercialisation of land use rights, enabling cities to assign land either by allocation, whereby land is dispensed at relatively low price to specific state-owned or non-profit users with no time limits (e.g. a university), or by conveyance, whereby for a higher fee the buyer can resell such rights to others (e.g. a foreignowned firm) or pledge them as security with a financial institution against a loan. Expropriation can be used as a mechanism to 'reallocate' land originally assigned by allocation to the same or new owners via conveyance. Within the rural areas, the commune decides the land used for agricultural and non-agricultural purposes, but participation to the lucrative secondary rural-commercial land market can occur only via the expropriation by the state, which can then reassign the land by conveyance.
} 
access to local public sector jobs and their associated benefits, like unemployment subsidies, health insurance, and old-age pensions (Chan, 2008; Cai, Fang and Zhao, 2009; Frijters, Lee and Meng, 2010). As a result, migrants work more hours, have lower wages, jobs of worse quality and tenure than those held by their urban hukou-holder counterparts (OECD, 2011; Meng, 2012). Despite markedly improved economic conditions over the past decade, current work documents that China's rural-urban migrants remain over-represented in "dirty, dangerous, and demeaning" urban jobs and in self-employment, especially in retail (Giulietti, Ning and Zimmermann, 2012). Being a rural-urban migrant however appears to be a signal for high effort and dependability, as in some places and for certain types of (demanding) jobs, migrants receive a higher rate of call-back relative to comparable urbanites (Kuhn and Shen, 2014).

The inequality between urbanites and migrants stemming from the hukou system is also highlighted as a possible cause of the poorer health status of migrants vis-à-vis urban hukou holders (Zhang and Kanbur, 2005), and the lower educational attainments of the children, who face tougher conditions about access to and costs of schooling (Robertson and Xu, 2008; Li, 2010; Wu, 2011; Giulietti, Biavaschi and Zimmermann, 2015).

The second stream of research focuses instead on the process and consequences of land expropriation following China's rapid economic expansion and urbanization. This literature comprises a heterogeneous group of studies with respect to focus and methodology. Several qualitative or theoretical studies document the process of urbanization in China, and its effect on the evolution of social and economic norms of the former rural community into an urban society (Siciliano, 2012; Xu, Tang and Chan, 2011; Sargeson and Song, 2010; Wang and Weaver, 2013; Tao and $\mathrm{Xu}, 2007)$.

Other works focus on the unfairness of the compensation received by the expropriated and the need to develop a fairer compensation system as a way to reduce inequality and social injustice. Standard practice bases the compensation amount to the value of the average annual output of the land in the three years prior to expropriation without any consideration for the increment in value that accrues after conversion to non-agricultural use (Xian, 2011; Zou and Oskam, 2007).

A number of quantitative analyses discuss expropriation as a source of uncertainty for farmers, and explores its economic effects. Some work estimates the effects of expropriation on the degree of under-investment in rural communities. For example, less secure land tenure reduces investments in fertilisers that enhance productivity in the fields (Jacoby, Li and Rozelle, 2002). Other work shows that less secure land tenure and incomplete land property 
rights lower the probability of emigration to urban areas. Preventing would-be rural emigrants from participating in labour markets outside their commune generates an economic loss because of an inefficient use of (human) resources. Any initial imperfection in the spatial allocation of human capital created by the hukou system is therefore exacerbated by the lesser incentives to internal mobility (Mullan, Grosjean and Kontoleon, 2011).

By connecting the literatures on the hukou system and on expropriation we not only fill a gap about this unknown aspect of China's economic development, but identify a source of exogenous shock that can be used to analyse the effects of a change in legal rights on several individual decisions and outcomes.

\section{Data}

The RUMiC data used in this analysis are extracted using identical information contained in the 2008 and 2009 Urban Household Survey (UHS), the Rural Household Survey (RHS), and the Migrant Household Survey (MHS). The RHS comprises around 8,000 households, while the UHS and MHS each involve around 5,000 households. Urban (rural) residents are individuals holding urban (rural) hukous. A migrant is defined as an individual who has rural hukou, but is living and surveyed in a city at the time of the survey. Migrants coming from the same province of the city where the survey takes place can be separately identified from those coming from other provinces.

The RUMiC survey covers principal migrant sending and receiving regions. The RHS was conducted in villages across nine provinces, while the UHS and MHS were carried out in nineteen and fifteen cities, respectively, of fewer provinces. Summary statistics across the three samples are presented in Table 1.

\section{[Table 1]}

There are marked differences but also similarities between the household members in the three surveys. Migrant households differ from urban or rural households in the age of family heads (20 years) and their spouses (15) years though not in that of their children, reflecting that the migrant sample has a higher incidence of singles than both urban and rural samples. Migrants have a similar incidence of male household heads than urbanites (about $66 \%$ ), which is substantially lower than that in the rural sample (95\%).

Migrants have on average 9 years of education, well below the 11 years of the urbanites but above the 7-8 years of rural stayers, from which they self-select. With reference to labour market outcomes, migrant household members work far more hours than household members surveyed in the other samples, have a higher incidence of temporary work and self- 
employment, and earn substantially less income than the urbanites, supporting the large empirical evidence of a dual urban labour market in China's cities. Unfortunately the rural sample contains no information on the type of job, since most people are self-employed on land allocated by the commune.

To carry out the analysis across each household member we focus separately on male household heads in working age (18-60), their working age spouses, and their children but only if aged 10-20 at the time of survey. The truncation in the children age enables us to focus on the critical age where holding a rural or urban hukou could have made a difference in accessing schooling at subsidized prices at the time of expropriation with change in legal rights. The truncation covers children from age 5 at time of expropriation (start formal schooling) up to 15 facing whether to continue their education beyond mandatory schooling (Junior High). We exclude older children because of the limited number of observations that would be added and because the choice of enrolling in a university degree involves far more heterogeneous variables than those related to continue education at Senior High level (e.g. preference for a subject, expectations about the future labour market).

As RUMiC questionnaire include a question of whether a respondent's hukou has changed and if so why, we are able to identify those experiencing land expropriation and change in legal rights as our treated group. These questions are asked only in the urban and rural sample. Most expropriated (85\%) are drawn from the urban sample, which covers medium- and large-size cities, while the remaining observations are sourced from the rural sample, which covers rural areas as well as small-sized urban centres.

The counterfactual group is ideally represented by households that are identical in everything to the treated but do not experience expropriation with a change in legal rights. Unfortunately there is no such a sample within RUMiC and hence we construct five relevant reference groups. Two of these are extracted from the urban sample: (i) native urbanites, who never experienced a change in their urban hukou; and (ii) current urban hukou holders who changed their status as a result of their high educational attainment. This group gathers rural hukou holders moving to a city for tertiary education and staying on as employees of organisations that sponsor their hukou change. These individuals are therefore highly skilled and educated. Two reference groups are extracted from the migrant sample: (iii) rural hukou migrants from the same province of the urban area where they were surveyed; (iv) rural hukou migrants from other provinces than that of the city where they are surveyed. The final reference group is represented by (v) rural hukou stayers, and who hold a rural hukou and live in an agricultural area, as was the case for the treated before expropriation. 
As discussed below the characteristics of the control groups bound those of the treated with reference to both demographics and labour market outcomes.

\section{Household heads}

The characteristics of male household heads aged 18-60 for treated and control groups are reported in Table 2, while Table 3 shows the t-test of mean differences. The treated (group (0)) are similar to the stayers in the urban (column: (1)) and rural control groups (5) with reference to average age (50 years), marital status (95\%), and number of children - the 1.4 average is mid-way between the corresponding averages for urban (1 child) and rural controls ( 2 children), as well as for labour market experience (30 years).

They are instead substantially different from the other category of hukou changers (group (2)), the highly skilled, who have a lower average age (39.5 versus 46.5 ). The treated also differ substantially from migrants (groups (3) and (4)), who are much younger and more likely to be single.

The treated group is similar to migrants with respect to the years of education $(9$, or mid-way between rural and urban stayers) and income, but share no other labour market characteristic. The treated group's hours of work ( $\sim 50$ vs. $60+$ amongst migrants), type of job and probability of self-employment are closer to those of urban stayers. No similarity in labour market outcome exists between the treated and the highly skilled, who have a much higher level of human capital (14.5 years versus 9.2), income (3,696 yuan/month versus 1,924 yuan/month), and probability of working in a permanent job (95\% versus $63 \%){ }^{2}$

\section{Female spouses}

Tables 4 summarises the characteristics of female spouses aged 18-60 while the results of t-test of mean differences are reported in Table 5. Female spouses from treated households share demographic characteristics and labour market experience with their urban (1) and rural (5) counterparts, while they have a similar amount of human capital as migrant female spouses (columns (3) and (4)). They, however, work more hours than their urban counterparts, including the highly skilled (2), but earn less income and are more likely to work in temporary jobs or as self-employed. Still, the treated group's labour market outcomes

\footnotetext{
${ }^{2}$ The questionnaire asked individuals who have their hukou changed from "rural" to "urban" about the reasons for the change; one of the responses to this question is through "education". Typically, in China, individuals from rural areas could get urban hukou by enrolling in higher education (attending university for example). We assume that respondents who answered this question by saying "education" are positively selected by cities as high-skilled individuals. The distribution of educational attainment of this group shows that $70 \%$ individuals have tertiary educational experience.
} 
are considerably better than those of migrant female spouses as they work substantially less hours per week (49 versus 70), earn more income (1,572 yuan/month versus 1,100-1,300 yuan/month), and have a much lower incidence of self-employment (15\% versus $\sim 40 \%$ ).

\section{Children}

The characteristics of the children of treated and non-treated families, aged 10-20 at the time of survey, are summarised in Table 6, while Table 7 reports the t-tests of mean differences. Children share a similar age (about 15) and gender (the only exception here is the highly skilled group) across all groups. The children of the treated group however have a much lower incidence of disability than those of rural and far-away migrant families $(0.007$ versus 0.02), and a relatively low level of education (8.9 years) vis-à-vis the children of every other households but those of rural stayers ( 8.8 years).

The children of the treated group have parents with a level of education comparable to those of migrants from nearby areas (about 8.5 years), mid-way between those of urbanites and rural stayers, but their parents' income is above those of migrant and rural families and only slightly less than those of comparable children of parents with urban hukou status (though there are only 18 observations for children of the highly skilled, limiting the reliability of comparisons with this reference group).

\section{Methodology and results}

The lack of additional details on the circumstances of the treatment is potentially problematic as the expansion of Chinese cities is unlikely to have uniformly embraced their agricultural surroundings at the same pace. Geographic constraints have probably affected the location choices of investments related to expropriation (e.g. large infrastructure such as ports, airports and so on) and this, in turn, might have affected residential choices, introducing selectivity issues to be accounted for in a regression analysis. We do not see this as a problem because the hukou system has effectively fixed the distribution of the registered population to that of 1958, with no real possibility for spatial arbitrage. Though people can move, their residence status (hukou) effectively does not. As a result, the expropriation with change in hukou type can be viewed as an exogenous shock, capable of identifying the premium of an urban over a rural hukou for several outcome variables. 


\subsection{Wage effects}

We first study the effect of expropriation and change in legal rights on the labour market outcomes of parents. Hence we run separate Ordinary Least Square regressions on male household heads and their female spouses based on the following functional form:

$$
\ln \mathrm{w}_{\mathrm{imt}}=\alpha+\mathbf{X}_{\mathrm{imt}} \beta+\delta \mathrm{E}_{\mathrm{imt}}+\gamma_{\mathrm{m}} \mathrm{P}_{\mathrm{m}}+\varepsilon_{\mathrm{imt}}
$$

where $\ln w$ is the logarithm of the hourly wage of individual $i$ living in province $m$ at time $t$, the matrix $\mathbf{X}$ includes demographic (marital status, disability status and the number of children) and labour market (years of experience, level of completed education, type of job) characteristics, $E_{i m t}$ is a dummy variable equal to 1 if the individual has obtained an urban hukou due to expropriation while zero corresponds to one of the five reference groups (i.e. we run five separate regressions, one for each control group), $P_{m}$ is a province fixed effect, and $\varepsilon$ is a random error term. Estimates are performed using robust standard errors to control for heteroskedaticity. Errors are clustered at individual level to capture the pooled nature of the sample, surveyed in 2008 and 2009.

\section{Male household heads}

The results obtained on male household heads aged 18-60 are reported in Table 8. The estimates are reported with their standard errors in parentheses. The table is constructed so that different control groups are represented across columns.

Model (1) explains about a third of the wage variance when the control group refers to urbanites and migrants from close-by (first three columns), while the fit is poorer in the case of migrants from far away, possibly due to the higher heterogeneity in labour market outcomes for this group, and in the case of rural stayers, due to lack of information on the type of job they hold.

Expropriation with changes in legal rights is always statistically significantly different from zero, implying that treated male household heads are affected by it. The effect however differs across control groups: the treated earn on average $14.4 \%$ less per hour than a comparable native urban hukou non-changer and $65 \%$ less than a highly skilled hukouchanger. However they earn more than males in the remaining control groups: $+16.5 \%$ vis-àvis migrants from nearby, $+34.9 \%$ relative to migrants from far away, and $+15.7 \%$ relative to rural stayers. These results hold also when we control for selection into employment, which is not reported here as the selection term is not statistically different from zero. 
All variables have the expected sign and statistical significance: a year of schooling is associated with a return ranging between $7 \%$ (native urbanites, first column) and $4.4 \%$ (migrants far away, fourth column) - the non-significance arising in the case of rural stayers probably reflects the lack of job information for this group. Labor market experience matters, at a decreasing rate, and so does the type of job held: the penalty for having a temporary job relative to a permanent one is as high as $58 \%$ in the case of native urbanites (first column). Being disabled is also associated with lower wages, as is having children, though the underlying marginal effect is statistically zero except when the control group covers only rural stayers. In contrast, there is a wage premium for being married, which can be substantial. Different trends across cities are captured in model (1) by the province fixed effects, which control for structural differences in sectorial composition of employment and occupations, openness to trade, and local institutions across different areas.

\section{Female spouses}

Broadly similar results occur also in the case of the female spouses aged 18-60. These are summarized in Table 9. Expropriation with a change in hukou rights has a negative marginal effect on the hourly wage of the treated female spouses relative to their counterparts holding an urban hukou. The effect is substantial: $-13 \%$ compared to native urban hukou holders and $-51 \%$ in the case of the highly skilled. However, it has a positive effect relative to what comparable females earn in rural areas $(+23 \%)$, and no effect relative to the hourly wages obtained by rural migrant spouses. This latter result may suggest that treated females hold jobs at the bottom of the occupational scale (unskilled).

The results show the presence of positive returns to education (range: 3-7\%), though females do not seem to benefit from experience (returns are zero). Temporary employment is associated with a substantial wage penalty ( $-46 \%$ in the case of native urban hukou holders) while less clear evidence arises in the case of self-employment: there is a penalty only in the case of native urban hukou holders, suggesting that urban spouses may negatively select into self-employment, perhaps as they cannot find jobs otherwise. Treated females are far less likely to work in a temporary job relative to their migrant counterparts $(-17.7 \%$ relative to nearby migrants and $-18.2 \%$ relative to those from far away).

\subsection{Job quality effects}

We complement the analysis of earnings with an analysis of the treatment's effects on job quality. In particular we study the probability of holding a permanent job using a multinomial logit model: 


$$
p\left(y_{i}=j\right)=\frac{\exp \left(Z_{j i}^{\prime} \pi_{j}\right)}{1+\sum_{l=2}^{k} \exp \left(Z_{l i}^{\prime} \pi_{l}\right)}
$$

where $y$ in the above model refers to the observed outcome characterising individual $i, j$ is one of the $k$ possible types of employment, and $\boldsymbol{Z}$ is a set of case-specific regressors that include demographic characteristics, the dummy variable identifying the treatment, a time dummy variable, and the province fixed effects. Estimation of model (2) is carried out through maximum likelihood methods, and all regressions are performed controlling for heteroskedasticity across sub-groups (robust estimation). ${ }^{3}$ The exponentiated coefficients, interpreted as relative risk ratios of being in a temporary job or self-employed as opposed to being in a permanent job (the base category), for expropriated male household heads and their spouses are presented in Table 10. A coefficient greater than one indicates that the treated are more likely to have the outcome reported (across rows) than the corresponding control group (across columns).

Relative to native urban hukou holders (first columns on left) both treated male household heads and their spouses are more likely to hold a temporary job (coefficients of 1.680 and 1.534 , respectively, and statistically significantly different from zero). At the same time, both treated males and females are less likely to hold temporary jobs than migrants or be self-employed. Expropriation with change in legal rights therefore seems to affect the treated household parents via a better job quality: an improved contractual tenure of the job, and the attachment to an employer as opposed to reliance on self-employment. We discuss next the various channels through which the treatment affects the labor market outcomes of the treated.

\subsection{Channels of transmissions}

To understand the possible channels through which the treatment generates its effects on labor market outcomes, we interact the treatment dummy with four sets of explanatory variables, one at the time: the age group, employer's ownership type, search method to get a job, and location (province). For each of these variables we run the modified version of model (1):

$$
\ln \mathrm{w}_{\mathrm{imt}}=\alpha+\mathbf{X}_{\mathrm{imt}} \beta+\delta \mathrm{E}_{\mathrm{imt}}+\mathbf{Y}_{\mathrm{imt}} * \mathrm{E}_{\mathrm{imt}} \mu+\gamma_{\mathrm{m}} \mathrm{P}_{\mathrm{m}}+\varepsilon_{\mathrm{imt}}
$$

\footnotetext{
${ }^{3}$ Due to lack of sufficient number of observations, we were not able to perform the job type analysis with high skilled urban hukou holders.
} 
In the above regression, $\mathbf{Y}$ contains a sub-set of the variables of $\mathbf{X}$. We restrict our focus to male household heads only, as they constitute the group for which we find the strongest treatment effects. ${ }^{4}$ Table 11 summarises the marginal effects obtained from model (3) and reports the statistical significance of the linear combination between the coefficient of a variable and that of its interaction with the expropriation dummy.

The results reveal that the wage effects of the treatment to the other urban hukou holders are driven by those with more labour market experience (aged 30+), while there is no wage penalty amongst the youngest group (aged 25-30). Conversely, the wage premium enjoyed by the treated over migrants arises only in the case of more experienced workers (aged $40+$ or $50+$ in the case of migrants from nearby areas). These results are consistent with the hypothesis that the change in legal rights rewards labour market experience only relative to those having incomplete rights to access the local labour market. This situation may arise if the treated gain access to public or other relatively well-paid sector jobs (out-of-reach for most migrants) in which they occupy positions at the bottom of the occupational scale, or if they get more favourable employment conditions, such as permanent jobs, as highlighted by the results reported in Table 10 .

The hypothesis that the treated experience a wage premium relative to migrants because they have access to government jobs is only partly supported by empirical evidence. The treated have a higher probability of getting a public sector job vis-à-vis migrants from far away, but they do not appear to have a differential likelihood of accessing government jobs relative to migrants from nearby. They are also less likely to access SOEs relative to native urban hukou holders, and SOEs and foreign-owned companies in the case of the highly skilled. The type of employer hence seems have substantial influence in explaining the wage penalty of treated male household heads relative to other urban hukou holders, but the lack of uniform evidence arising when the treated are compared to migrants suggests that the differential wage outcomes between these two groups arises from the type of employment (permanent or temporary) rather than the characteristics of the employer.

Clearer differences between treated and migrants however emerge in the search method to find a job as the last panel of Table 11 shows. Here the treated experience a wage premium relative to migrants and rural stayers thanks to jobs found via government agencies and personal networks rather than direct application to employers. As the treated are

\footnotetext{
${ }^{4}$ The results for female spouses are available from authors upon request.
} 
effectively 'local' to the city to which they have been admitted, they are likely to have a better support group of friends and relative than migrants from far away. At the same time, the treated are much less likely to get a job via a government agency than native urban hukou holders and the highly skilled. This result provides further support that the government, which carries out the expropriation and the change in legal rights, seems to help the treated to find a job in the urban area (Job however for which the treated might only partially qualify).

The analysis of interactions by province (not reported but available from the authors) highlights the idiosyncrasy of expropriation and change in hukou status, as significant interaction effects occur in certain local areas. For example, there are strong positive treatment effects relative to native urban hukou residents and far-away migrants in Chongqing, where the survey captures areas expropriated for the construction of the new airport. It is possible that expropriation and the change in legal rights have enabled those living nearby the new Chongqing airport to obtain better jobs in the new infrastructure. There are also substantial positive treatment effects relative to migrants in Guangdong, which benefited from the early introduction of the economic reforms that started in 1978. It is possible that those expropriated have especially benefited from jobs created from the large inflow of domestic and foreign investments subsequently to economic reforms, which have transformed the Pearl River delta into one of China's prime manufacturing and export areas.

\subsection{Children education}

In addition to the labor market outcomes of parents, we study the effect of the treatment on the education of the treated children using the Ordinary Least Square regression:

$$
e^{d u_{i m t}}=\mathrm{a}+\mathbf{R}_{\mathrm{imt}} \mathrm{b}+\mathrm{dE}_{\mathrm{imt}}+\mathrm{g}_{\mathrm{m}} \mathrm{P}_{\mathrm{m}}+\eta_{\text {imt }}
$$

where $e d u$ is the number of years of education of child $i$ aged 10-20 living in province $m$ at time $t$, the matrix $\mathbf{R}$ includes demographic (age, gender, disability status, number of siblings) and family background (parental education and wages) characteristics, $\mathrm{E}_{\mathrm{imt}}$ is a dummy variable equal to 1 if the child has obtained an urban hukou due to expropriation while zero corresponds to one of the five reference groups, $P_{m}$ is a province fixed effect, and $\eta_{\mathrm{imt}}$ is a random error term. Estimates are performed using robust standard errors and errors are clustered at individual level.

Table 12 reports the results. Model (4) explains more than half of the variance in years of schooling across children aged 10-20 at the time of survey. Receiving an urban hukou after expropriation is associated with a similar educational attainment across the treated children, 
those of native urban hukou holders and those of the highly skilled. There is no statistical difference between the years of education of these three groups, implying that at least up to age 20 at the time of the survey, expropriation has effectively led to similar educational outcomes for children of parents characterized by very different levels of skills and labour market outcomes.

In contrast, the children of the treated complete almost a $0.7+$ year of extra schooling relative to the children of migrants and 1.5 additional years of schooling vis-à-vis the children of the rural stayers. These results probably reflect the differential access and price for education for children holding urban and rural hukou. A casual interpretation of the results suggests that switching from rural to urban hukou may lead to a reduction in intergenerational differences in educational outcomes, at least up to the end of Senior High School.

\section{Conclusions}

This paper exploits a quasi-natural experiment (a change in hukou status due to expropriation) to study the labor market outcomes of male household heads aged 18-60 and their spouses, and the educational outcomes of their children aged 10-20. We find strong evidence that those who changed their hukou status to an urban hukou have better labour market outcomes than comparable rural stayers and migrants, and hence catch up with native urbanites in terms of wages and job quality. We find that such effects occur through older age, job search method, and the contractual relationship with the employer.

We also find that children experiencing a hukou change due to expropriation have a similar investment in human capital as the children of native urban hukou holders. Leveling the hukou status amongst children in an urban area by removing differences in access to schooling and the price of education appear to eliminate intergenerational differences in educational investment up to age 20, regardless of the differences in parental background.

The results confirm the hukou status as a strong economic determinant of labour market outcomes and as a source of inequality. This source of inequality is not only restricted to individual household head, but also applies to family members of the whole household. Our results also suggest that a way to reduce inequalities may begin with an equal access to schooling for the children of those living in the cities. The Chinese central government has 
realized serious problems associated with the current hukou system and is on its way to make fundamental changes. ${ }^{5}$

\footnotetext{
${ }^{5}$ In modern China, "hukou" has been the "root" of many kinds of inequalities between a "rural" person and an "urban" person regardless of their place of residences. In July of 2014, the National State Department of Chinese government has again issued a nation-wide policy guideline regarding further reforming the current hukou registration system. One of the major objectives of the hukou reform is to remove differences (between urban hukou holders and rural hukou holders) in the rights to access public services, such as education, employment opportunities, medical insurance, pension and urban housing arrangements etc. By the end of November 2014, four major agricultural provinces (Xinjiang, Henan, Heilongjiang, and Hebei) have already issued provincial government policies dedicated to reform the hukou system by removing urban and rural hukou differences and setting up institutions that promote equal rights for both rural residents and urben residents in terms of accessing public services and goods. This clearly shows that the central government has long realized the problems associated with the hukou system and that it is determined the overhaul it in the near future.
} 


\section{References}

Akgüç, Mehtap, Corrado Giulietti, and Klaus F. Zimmermann, (2014) "The RUMiC longitudinal survey: fostering research on labor markets in China", IZA Journal of Labor \& Development, 2014, 3:5

Biavaschi, Costanza, Corrado Guilietti and Klaus F. Zimmermann, (2012) "Self-employment of rural-to-urban migrants in China", IZA Discussion Paper 7859.

Cai, Fang, (2011) "Hukou System Reform and Unification of Rural-urban Social Welfare", China \& World Economy, Vol. 19 N.3, pp.33-48.

Cai, Fang, Albert Park and Yao-Hui Zhao (2009) "The Chinese labor market in the Reform Era", in Brandt, Lauren and Thomas Rawski China's Great Economic Transformation, pp. 167-214. Cambridge University Press.

Chan, Kam Wing, (2008) "Internal Labor Migration in China: Trends, Geographical Distribution and Policies," Proceedings of the United Nations Expert Group Meeting on Population Distribution, Urbanization, Internal Migration and Development, UN/POP/EGM-URB/2008/05, United Nations, pp.93-122.

Chan, Kam Wing, (2009) "The Chinese Hukou System at 50", Eurasian Geography and Economics, Vol50, No. 2, pp.197-221.

Chan, Kam Wing and William Buckingham (2008). "Is China abolishing the Hukou system?", The China Quarterly, Vo. 195, pp.582-606.

Chan, Kam Wing, Ta Liu and Yunyan Yang (1999) "Hukou and Non-hukou migrations in China: comparisons and contrasts", International Journal of Population Growth, Vol.5, pp.425-448.

Frijters, Paul, Leng Lee and Xin Meng (2010) “Jobs, working hours, and remuneration packages for migrants and urban residents, in Xin Meng, Chris Manning, S. Li and T.N. Effendi (eds.) The Great migration: rural-urban migration in China and Indonesia. Cheltenham: Edward Elgar Publishing. 
Giulietti, Corrado, Guangjie Ning and Klaus F. Zimmermann, (2012) "Self-employment of rural-to-urban migrants in China", International Journal of Manpower, Vol. 33 Iss: 1, pp. $96-117$.

Jocoby, Hanan G, Guo Li and Scott Rozelle, (2002) "Hazards of Expropriation: Tenure Insecurity and Investment in Rural China", The American Economic Review, Vol 92, No.5 pp.1420-1447.

Kuhn, Peter, and Kailing Shen, (2014) "Do Employer Prefer Undocumented Workers? Evidence from China's Hukou System", IZA Working Paper 8289.

Li, Chunling (2010) "Tertiary education expansion and inequality in education opportunity" Sociology Research, Vol 3, pp.1-34. (in Chinese)

Lin, George C.S and Samuel P.S Ho, (2003a) "China's land resources and land-use change: insights from the 1996 land survey", Land Use Policy, Vol 20, pp.87-107.

Lin, George C.S and Samuel P.S Ho, (2003b) "Emerging Land Markets in Rural and Urban China: Policies and Practices", The China Quarterly, Vol 175, pp.681-707.

Meng, Xin, (2012) "Labor Market Outcomes and Reforms in China", The Journal of Economic Perspectives, Vol 26, No.4 pp.75-101.

Mullan, Katrina, Pauline Grosjean and Andreas Kontoleon, (2011) "Land Tenure Arrangements and Rural-Urban Migration in China", World Development, Vol 39, No.1 pp.123-133.

OECD (2011) Divided we stand: why inequality keeps rising. Paris: Organisation for Economic Co-operation and Development

Robsertson, Peter and Jessica Xu (2008) "Education investment in China and its implications for China and East Asia”, Researchgate.net, http://www.researchgate.net/publication/255579007_Education_Investment_in_China _and_its_Implications_for_China_and_East_Asia 
Sargeson, Sally and Yu Song, (2010) "Land Expropriation and the Gender Politics of Citizenship in the Urban Frontier", The China Journal, Vol 64, pp.19-45.

Siciliano, Giuseppina, (2012) "Urbanization strategies, rural development and land use changes in China: A multiple-level integrated assessment”, Land Use Policy, Vol 29, pp.165-178.

Tao, Ran and Zhigang Xu (2007) "Urbanization, rural land system and social security for migrants in China", Journal of Development Studies, Vol 43, No 7, pp.1301-1320.

Xian, Zhang (2011). Seeking just compensation for collective-owned land expropriation in China. Unpublished Hons. thesis, Peking University School of Transnational Law.

$\mathrm{Xu}$, Ying, Bo-sin Tang and Edwin H.W. Chan, (2011) "State-led land requisition and transformation of rural villages in transitinal China", Habitat International, Vol 35, pp.57-65.

Wang, Fei-Ling (2005). China's household registration (Hukou) system: discrimination and reform. Statement made before the Congressional Executive Commission on China. Unpublished mimeo.

Wang, Xiaobing and Nick Weaver (2013). Surplus labour and urbanizaiton in China. Unpublished mimeo. University of Manchester.

Wu, Xiaogang (2011) "The household registration system and rural-urban educational inequality in contemporary China" Report 11-735, Population Study Center, University of Michigan.

Zhang, Xiaobo and Ravi Kanbur (2005) "Spatial inequality in education and health care in China", China Economic Review, Vol. 33, No. 1, pp.189-204.

Zou, Xiuqing and Arie J. Oskam, (2007) "New Compensation Standard for Land Expropriation in China", China \& World Economy, Vol. 15, No.5 pp.107-120. 
Table 1 Summary Statistics of Selected Variables for All Household Members

\begin{tabular}{|c|c|c|c|c|c|c|c|c|c|}
\hline & \multicolumn{3}{|c|}{ Migrant survey } & \multicolumn{3}{|c|}{ Rural Survey } & \multicolumn{3}{|c|}{ Urban survey } \\
\hline & Household head & Spouse & Children & Household head & Spouse & Children & Household head & Spouse & Children \\
\hline \multirow[t]{2}{*}{ Age } & 31.27 & 36.33 & 14.92 & 51.83 & 49.25 & 16.30 & 51.53 & 50.07 & 15.35 \\
\hline & (10.53) & $(8.91)$ & (3.13) & (10.12) & (10.57) & (2.93) & (12.81) & (12.25) & (3.180) \\
\hline \multirow[t]{2}{*}{ Male } & 0.685 & 0.260 & 0.549 & 0.957 & 0.0624 & 0.507 & 0.640 & 0.319 & 0.518 \\
\hline & $(0.465)$ & $(0.439)$ & $(0.498)$ & $(0.202)$ & $(0.242)$ & $(0.500)$ & $(0.480)$ & $(0.466)$ & $(0.500)$ \\
\hline \multirow[t]{2}{*}{ Disable } & 0.031 & 0.029 & 0.029 & 0.055 & 0.056 & 0.020 & 0.037 & 0.029 & 0.011 \\
\hline & $(0.173)$ & $(0.167)$ & $(0.167)$ & $(0.228)$ & $(0.231)$ & $(0.141)$ & $(0.189)$ & $(0.167)$ & $(0.102)$ \\
\hline \multirow[t]{2}{*}{ Education (years) } & 9.400 & 8.431 & 8.965 & 7.474 & 6.547 & 8.977 & 11.18 & 10.92 & 7.959 \\
\hline & $(2.514)$ & $(2.531)$ & $(2.342)$ & $(2.348)$ & $(2.472)$ & $(1.923)$ & $(3.556)$ & $(3.450)$ & $(3.307)$ \\
\hline \multirow[t]{2}{*}{ Hours worked (week) } & 62.02 & 67.70 & 64.04 & 51.18 & 50.62 & 55.86 & 43.61 & 43.46 & 44.65 \\
\hline & $(17.62)$ & $(19.98)$ & $(20.46)$ & $(17.21)$ & $(16.91)$ & $(15.09)$ & $(13.72)$ & $(12.51)$ & $(10.98)$ \\
\hline \multirow[t]{2}{*}{ Income (month, yuan) } & 1769.3 & 1488.5 & 924.8 & 1573.0 & 1147.9 & 1072.9 & 2658.0 & 2387.1 & 999.2 \\
\hline & (1780.3) & (1458.0) & (1069.4) & (2028.9) & (1114.7) & (434.8) & $(2753.1)$ & (2697.4) & $(468.3)$ \\
\hline \multicolumn{10}{|l|}{ Job type } \\
\hline \multirow[t]{2}{*}{ Permanent } & 0.429 & 0.312 & 0.294 & & & & 0.779 & 0.757 & 0.444 \\
\hline & $(0.495)$ & $(0.463)$ & $(0.457)$ & & & & $(0.415)$ & $(0.429)$ & $(0.511)$ \\
\hline \multirow[t]{2}{*}{ Temporary } & 0.348 & 0.273 & 0.574 & & & & 0.137 & 0.166 & 0.500 \\
\hline & $(0.476)$ & $(0.445)$ & $(0.496)$ & & & & $(0.344)$ & $(0.372)$ & $(0.514)$ \\
\hline \multirow[t]{2}{*}{ Self-employed } & 0.223 & 0.415 & 0.132 & & & & 0.084 & 0.078 & 0.056 \\
\hline & $(0.416)$ & $(0.493)$ & $(0.340)$ & & & & $(0.277)$ & $(0.268)$ & $(0.236)$ \\
\hline Obs. & 10465 & 4077 & 1352 & 15990 & 15917 & 4264 & 9656 & 8501 & 2548 \\
\hline
\end{tabular}

Source: RUMiC (2008-2009). 
Table 2 Summary Statistics across Different Groups (Male household heads)

\begin{tabular}{|c|c|c|c|c|c|c|}
\hline & $\begin{array}{c}\text { Treated Group } \\
(0) \\
\text { Expropriated } \\
\text { (urban + rural) }\end{array}$ & $\begin{array}{c}\text { (1) } \\
\text { Urban hukou } \\
\text { non-changers }\end{array}$ & $\begin{array}{c}(2) \\
\text { High education } \\
\text { hukou } \\
\text { changers } \\
\end{array}$ & $\begin{array}{l}\text { Control groups } \\
\text { (3) } \\
\text { Migrants from } \\
\text { close-by }\end{array}$ & $\begin{array}{c}\text { (4) } \\
\text { Migrants from } \\
\text { far away }\end{array}$ & Rural stayers \\
\hline Age & $\begin{array}{c}46.51 \\
(7.977)\end{array}$ & $\begin{array}{c}47.35 \\
(8.886)\end{array}$ & $\begin{array}{c}39.47 \\
(7.839)\end{array}$ & $\begin{array}{c}33.69 \\
(10.62)\end{array}$ & $\begin{array}{c}31.80 \\
(9.955)\end{array}$ & $\begin{array}{c}48.17 \\
(7.460)\end{array}$ \\
\hline Married & $\begin{array}{c}0.979 \\
(0.143)\end{array}$ & $\begin{array}{c}0.964 \\
(0.187)\end{array}$ & $\begin{array}{c}0.952 \\
(0.214)\end{array}$ & $\begin{array}{c}0.656 \\
(0.475)\end{array}$ & $\begin{array}{c}0.601 \\
(0.490)\end{array}$ & $\begin{array}{c}0.978 \\
(0.145)\end{array}$ \\
\hline Children & $\begin{array}{c}1.418 \\
(0.606)\end{array}$ & $\begin{array}{c}1.032 \\
(0.355)\end{array}$ & $\begin{array}{c}1.043 \\
(0.541)\end{array}$ & $\begin{array}{c}1.074 \\
(0.802)\end{array}$ & $\begin{array}{c}1.064 \\
(0.876)\end{array}$ & $\begin{array}{c}1.906 \\
(0.746)\end{array}$ \\
\hline Disable & $\begin{array}{l}0.0647 \\
(0.246)\end{array}$ & $\begin{array}{l}0.0312 \\
(0.174)\end{array}$ & $\begin{array}{l}0.0309 \\
(0.173)\end{array}$ & $\begin{array}{l}0.0320 \\
(0.176)\end{array}$ & $\begin{array}{l}0.0293 \\
(0.169)\end{array}$ & $\begin{array}{l}0.0482 \\
(0.214)\end{array}$ \\
\hline Education (years) & $\begin{array}{c}9.229 \\
(2.580)\end{array}$ & $\begin{array}{c}11.72 \\
(3.250)\end{array}$ & $\begin{array}{c}14.48 \\
(2.763)\end{array}$ & $\begin{array}{c}9.224 \\
(2.625)\end{array}$ & $\begin{array}{c}9.380 \\
(2.453)\end{array}$ & $\begin{array}{c}7.650 \\
(2.203)\end{array}$ \\
\hline Experience & $\begin{array}{c}30.90 \\
(9.289)\end{array}$ & $\begin{array}{c}29.62 \\
(10.56)\end{array}$ & $\begin{array}{c}18.45 \\
(8.530)\end{array}$ & $\begin{array}{c}18.30 \\
(11.61)\end{array}$ & $\begin{array}{c}16.01 \\
(10.93)\end{array}$ & $\begin{array}{c}34.16 \\
(8.320)\end{array}$ \\
\hline Hours worked (week) & $\begin{array}{c}49.81 \\
(14.06)\end{array}$ & $\begin{array}{c}44.44 \\
(15.23)\end{array}$ & $\begin{array}{c}41.91 \\
(10.07)\end{array}$ & $\begin{array}{c}64.43 \\
(16.56)\end{array}$ & $\begin{array}{c}62.05 \\
(18.01)\end{array}$ & $\begin{array}{c}51.95 \\
(17.17)\end{array}$ \\
\hline Income (month, yuan) & $\begin{array}{c}1924.0 \\
(1609.8)\end{array}$ & $\begin{array}{c}2833.5 \\
(3164.0)\end{array}$ & $\begin{array}{c}3696.3 \\
(2263.3)\end{array}$ & $\begin{array}{c}1758.7 \\
(2497.1)\end{array}$ & $\begin{array}{c}1945.3 \\
(1873.6)\end{array}$ & $\begin{array}{c}1632.8 \\
(2165.2)\end{array}$ \\
\hline Job type & & & & & & \\
\hline Permanent & $\begin{array}{c}0.632 \\
(0.484)\end{array}$ & $\begin{array}{c}0.802 \\
(0.399)\end{array}$ & $\begin{array}{c}0.950 \\
(0.218)\end{array}$ & $\begin{array}{c}0.337 \\
(0.473)\end{array}$ & $\begin{array}{c}0.459 \\
(0.498)\end{array}$ & \\
\hline Temporary & $\begin{array}{c}0.245 \\
(0.432)\end{array}$ & $\begin{array}{c}0.113 \\
(0.317)\end{array}$ & $\begin{array}{l}0.00826 \\
(0.0907)\end{array}$ & $\begin{array}{c}0.396 \\
(0.489)\end{array}$ & $\begin{array}{c}0.307 \\
(0.461)\end{array}$ & \\
\hline Self-employed & $\begin{array}{c}0.123 \\
(0.329) \\
\end{array}$ & $\begin{array}{l}0.0845 \\
(0.278)\end{array}$ & $\begin{array}{l}0.0413 \\
(0.199) \\
\end{array}$ & $\begin{array}{c}0.267 \\
(0.443) \\
\end{array}$ & $\begin{array}{c}0.234 \\
(0.423) \\
\end{array}$ & \\
\hline Obs. & 479 & 3783 & 291 & 1282 & 5667 & 11602 \\
\hline
\end{tabular}

Notes: The summary statistics for male household heads are limited to individuals of age 18-60 at the time of survey. The treated group consists of respondents who changed their hukou status to urban following expropriation.

Source: RUMiC (2008-2009). 
Table 3 T-test of Mean Differences (male household heads)

\begin{tabular}{|c|c|c|c|c|c|}
\hline & $\begin{array}{l}\text { Urban hukou } \\
\text { non-changers }\end{array}$ & $\begin{array}{l}\text { High education } \\
\text { hukou changers }\end{array}$ & $\begin{array}{l}\text { Migrants from } \\
\text { close-by }\end{array}$ & $\begin{array}{l}\text { Migrants from } \\
\text { far away }\end{array}$ & Rural stayers \\
\hline Age & $\begin{array}{l}0.844^{* *} \\
(2.15)\end{array}$ & $\begin{array}{c}-7.031^{* * *} \\
(-11.99)\end{array}$ & $\begin{array}{l}-12.82^{* * *} \\
(-27.27)\end{array}$ & $\begin{array}{l}-14.71^{* * * *} \\
(-37.94)\end{array}$ & $\begin{array}{c}1.666^{* * *} \\
(4.49)\end{array}$ \\
\hline Married & $\begin{array}{c}-0.0154^{* *} \\
(-2.13)\end{array}$ & $\begin{array}{c}-0.0272^{*} \\
(-1.92)\end{array}$ & $\begin{array}{l}-0.323^{* * *} \\
(-21.84)\end{array}$ & $\begin{array}{l}-0.378^{* * *} \\
(-41.03)\end{array}$ & $\begin{array}{c}-0.000759 \\
(-0.11)\end{array}$ \\
\hline Children & $\begin{array}{c}-0.386^{* * *} \\
(-13.49)\end{array}$ & $\begin{array}{c}-0.375^{* * *} \\
(-8.75)\end{array}$ & $\begin{array}{c}-0.344^{* * * *} \\
(-9.25)\end{array}$ & $\begin{array}{c}-0.354^{* * *} \\
(-11.48)\end{array}$ & $\begin{array}{l}0.488^{* * * *} \\
(16.91)\end{array}$ \\
\hline Disable & $\begin{array}{c}-0.0335^{* * *} \\
(-2.88)\end{array}$ & $\begin{array}{c}-0.0338^{* *} \\
(-2.23)\end{array}$ & $\begin{array}{c}-0.0327^{* * *} \\
(-2.67)\end{array}$ & $\begin{array}{c}-0.0354^{* * *} \\
(-3.09)\end{array}$ & $\begin{array}{l}-0.0165 \\
(-1.44)\end{array}$ \\
\hline Education (years) & $\begin{array}{l}2.486^{* * * *} \\
(16.61)\end{array}$ & $\begin{array}{l}5.246^{* * * *} \\
(23.90)\end{array}$ & $\begin{array}{c}-0.00553 \\
(-0.03)\end{array}$ & $\begin{array}{l}0.150 \\
(1.04)\end{array}$ & $\begin{array}{c}-1.580^{* * * *} \\
(-11.06)\end{array}$ \\
\hline Experience & $\begin{array}{l}-1.280^{* *} \\
(-2.40)\end{array}$ & $\begin{array}{c}-12.45^{* * *} \\
(-17.16)\end{array}$ & $\begin{array}{c}-12.60^{* * *} \\
(-20.23)\end{array}$ & $\begin{array}{c}-14.89^{* * *} \\
(-28.16)\end{array}$ & $\begin{array}{c}3.265^{* * *} \\
(6.34)\end{array}$ \\
\hline Hours worked (week) & $\begin{array}{c}-5.370^{* * *} \\
(-7.21)\end{array}$ & $\begin{array}{c}-7.896^{* * *} \\
(-8.60)\end{array}$ & $\begin{array}{l}14.62^{* * *} \\
(14.81)\end{array}$ & $\begin{array}{l}12.24^{* * *} \\
(15.81)\end{array}$ & $\begin{array}{c}2.141^{* * *} \\
(2.92)\end{array}$ \\
\hline Income (month, yuan) & $\begin{array}{c}909.5^{* * * *} \\
(9.36)\end{array}$ & $\begin{array}{c}1772.3^{* * *} \\
(11.28)\end{array}$ & $\begin{array}{l}-165.3 \\
(-1.55)\end{array}$ & $\begin{array}{l}21.28 \\
(0.26)\end{array}$ & $\begin{array}{c}-291.2^{* * *} \\
(-3.43)\end{array}$ \\
\hline \multicolumn{6}{|l|}{ Job type } \\
\hline Permanent & $\begin{array}{c}0.170^{* * * *} \\
(4.42)\end{array}$ & $\begin{array}{c}0.319^{* * * *} \\
(7.89)\end{array}$ & $\begin{array}{c}-0.295^{* * *} \\
(-7.35)\end{array}$ & $\begin{array}{c}-0.173^{* * *} \\
(-4.49)\end{array}$ & \\
\hline Temporary & $\begin{array}{c}-0.132^{* * *} \\
(-3.85)\end{array}$ & $\begin{array}{c}-0.237^{* * *} \\
(-6.91)\end{array}$ & $\begin{array}{l}0.151^{* * * *} \\
(4.12)\end{array}$ & $\begin{array}{c}0.0617^{*} \\
(1.79)\end{array}$ & \\
\hline Self-employed & $\begin{array}{l}-0.0382 \\
(-1.45)\end{array}$ & $\begin{array}{c}-0.0814^{* * *} \\
(-2.83) \\
\end{array}$ & $\begin{array}{l}0.145^{* * * *} \\
(5.05)\end{array}$ & $\begin{array}{c}0.111^{* * * *} \\
(4.22) \\
\end{array}$ & \\
\hline Obs. & 4262 & 770 & 1761 & 6146 & 12081 \\
\hline
\end{tabular}

Notes: The columns in this table are the results of the t-tests of differences between column (0) and columns (1)-(5) respectively from the previous table; therefore, the sample sizes correspond to the sum of sample sizes of column (0) and columns (1)-(5) respectively. Base group is land expropriated individuals in rural or urban surveys in each column (only household heads). T-statistics are in parentheses. ${ }^{*} p<0.10$, ${ }^{* * *} p<0.05,{ }^{* * *} p<0.01$

Source: RUMiC (2008-2009). 
Table 4 Summary Statistics across Different Groups (female spouses)

\begin{tabular}{|c|c|c|c|c|c|c|}
\hline & $\begin{array}{c}\text { Treated Group } \\
(0) \\
\text { Expropriated } \\
\text { (urban + rural) }\end{array}$ & $\begin{array}{c}\text { (1) } \\
\text { Urban hukou } \\
\text { non-changers }\end{array}$ & $\begin{array}{l}\text { (2) } \\
\text { High education } \\
\text { hukou changers }\end{array}$ & $\begin{array}{l}\text { Control Groups } \\
\text { (3) } \\
\text { Migrants from } \\
\text { close-by }\end{array}$ & $\begin{array}{c}\text { (4) } \\
\text { Migrants from } \\
\text { far away }\end{array}$ & $\begin{array}{c}\text { (5) } \\
\text { Rural stayers }\end{array}$ \\
\hline Age & $\begin{array}{c}47.57 \\
(10.31)\end{array}$ & $\begin{array}{c}50.01 \\
(12.19)\end{array}$ & $\begin{array}{c}39.29 \\
(12.56)\end{array}$ & $\begin{array}{c}37.85 \\
(9.854)\end{array}$ & $\begin{array}{c}35.15 \\
(8.548)\end{array}$ & $\begin{array}{c}49.60 \\
(10.07)\end{array}$ \\
\hline Married & $\begin{array}{c}0.995 \\
(0.071)\end{array}$ & $\begin{array}{c}0.998 \\
(0.039)\end{array}$ & $\begin{array}{c}0.990 \\
(0.101)\end{array}$ & $\begin{array}{c}0.995 \\
(0.067)\end{array}$ & $\begin{array}{c}0.997 \\
(0.051)\end{array}$ & $\begin{array}{c}0.987 \\
(0.112)\end{array}$ \\
\hline Children & $\begin{array}{c}1.539 \\
(0.704)\end{array}$ & $\begin{array}{c}1.261 \\
(0.641)\end{array}$ & $\begin{array}{c}1.161 \\
(0.629)\end{array}$ & $\begin{array}{c}1.370 \\
(0.692)\end{array}$ & $\begin{array}{c}1.368 \\
(0.716)\end{array}$ & $\begin{array}{c}2.055 \\
(0.805)\end{array}$ \\
\hline Disable & $\begin{array}{l}0.0559 \\
(0.230)\end{array}$ & $\begin{array}{l}0.0226 \\
(0.149)\end{array}$ & $\begin{array}{l}0.0255 \\
(0.158)\end{array}$ & $\begin{array}{l}0.0211 \\
(0.144)\end{array}$ & $\begin{array}{l}0.0226 \\
(0.149)\end{array}$ & $\begin{array}{l}0.0552 \\
(0.228)\end{array}$ \\
\hline Education (years) & $\begin{array}{c}8.183 \\
(2.975)\end{array}$ & $\begin{array}{c}10.77 \\
(3.250)\end{array}$ & $\begin{array}{c}13.64 \\
(3.299)\end{array}$ & $\begin{array}{c}8.305 \\
(2.728)\end{array}$ & $\begin{array}{c}8.210 \\
(2.531)\end{array}$ & $\begin{array}{c}6.386 \\
(2.398)\end{array}$ \\
\hline Experience & $\begin{array}{c}32.27 \\
(12.06)\end{array}$ & $\begin{array}{c}32.98 \\
(13.62)\end{array}$ & $\begin{array}{c}19.63 \\
(13.74)\end{array}$ & $\begin{array}{c}23.02 \\
(10.47)\end{array}$ & $\begin{array}{c}20.21 \\
(9.278)\end{array}$ & $\begin{array}{c}35.46 \\
(10.36)\end{array}$ \\
\hline Hours worked (week) & $\begin{array}{c}48.98 \\
(14.58)\end{array}$ & $\begin{array}{c}43.09 \\
(11.40)\end{array}$ & $\begin{array}{c}42.39 \\
(10.30)\end{array}$ & $\begin{array}{c}70.16 \\
(18.67)\end{array}$ & $\begin{array}{c}67.62 \\
(20.49)\end{array}$ & $\begin{array}{c}50.40 \\
(17.36)\end{array}$ \\
\hline Income (month, yuan) & $\begin{array}{c}1572.0 \\
(3387.1)\end{array}$ & $\begin{array}{c}2028.4 \\
(2588.6)\end{array}$ & $\begin{array}{c}2641.9 \\
(1609.2)\end{array}$ & $\begin{array}{c}1127.1 \\
(1021.3)\end{array}$ & $\begin{array}{c}1349.6 \\
(1074.2)\end{array}$ & $\begin{array}{c}1040.3 \\
(942.5)\end{array}$ \\
\hline \multicolumn{7}{|l|}{ Job type } \\
\hline Permanent & $\begin{array}{c}0.511 \\
(0.502)\end{array}$ & $\begin{array}{c}0.742 \\
(0.438)\end{array}$ & $\begin{array}{c}0.887 \\
(0.317)\end{array}$ & $\begin{array}{c}0.288 \\
(0.453)\end{array}$ & $\begin{array}{c}0.318 \\
(0.466)\end{array}$ & \\
\hline Temporary & $\begin{array}{c}0.336 \\
(0.474)\end{array}$ & $\begin{array}{c}0.182 \\
(0.386)\end{array}$ & $\begin{array}{c}0.0775 \\
(0.268)\end{array}$ & $\begin{array}{c}0.302 \\
(0.460)\end{array}$ & $\begin{array}{c}0.282 \\
(0.450)\end{array}$ & \\
\hline Self-employed & $\begin{array}{c}0.153 \\
(0.362)\end{array}$ & $\begin{array}{c}0.076 \\
(0.265) \\
\end{array}$ & $\begin{array}{c}0.035 \\
(0.185)\end{array}$ & $\begin{array}{c}0.410 \\
(0.492)\end{array}$ & $\begin{array}{c}0.400 \\
(0.490)\end{array}$ & \\
\hline Obs. & 590 & 4602 & 196 & 665 & 2298 & 14254 \\
\hline
\end{tabular}

Notes: The summary statistics for female spouses are limited to individuals of age 18-60 at the time of survey. The treated group consist of respondents who changed their hukou status to urban following expropriation.

Source: RUMiC (2008-2009). 
Table 5 T-test of Mean Differences (female spouses)

\begin{tabular}{|c|c|c|c|c|c|}
\hline & $\begin{array}{l}\text { Urban hukou non- } \\
\text { changers }\end{array}$ & $\begin{array}{l}\text { High education } \\
\text { hukou changers }\end{array}$ & $\begin{array}{l}\text { Migrants from } \\
\text { close-by }\end{array}$ & $\begin{array}{c}\text { Migrants from far } \\
\text { away }\end{array}$ & Rural stayers \\
\hline \multirow[t]{2}{*}{ Age } & $2.442^{* * *}$ & $-8.282^{* * *}$ & $-9.714^{* * *}$ & $-12.42^{* * *}$ & $2.028^{* * *}$ \\
\hline & $(5.30)$ & $(-8.35)$ & $(-17.00)$ & $(-26.98)$ & (4.69) \\
\hline \multirow[t]{2}{*}{ Married } & 0.00356 & -0.00512 & 0.000573 & 0.00247 & $-0.00755^{* *}$ \\
\hline & $(1.19)$ & $(-0.66)$ & $(0.15)$ & $(0.79)$ & $(-2.46)$ \\
\hline \multirow[t]{2}{*}{ Children } & $-0.278^{* * *}$ & $-0.379^{* * *}$ & $-0.169^{* * *}$ & $-0.172^{* * *}$ & $0.515^{* * *}$ \\
\hline & $(-9.08)$ & $(-7.03)$ & $(-4.27)$ & $(-5.25)$ & $(17.23)$ \\
\hline \multirow[t]{2}{*}{ Disable } & $-0.0333^{* * *}$ & $-0.0304^{* *}$ & $-0.0349^{* * *}$ & $-0.0333^{* * *}$ & -0.000755 \\
\hline & $(-3.43)$ & $(-2.06)$ & $(-3.17)$ & $(-3.34)$ & $(-0.08)$ \\
\hline \multirow[t]{2}{*}{ Education (years) } & $2.583^{* * *}$ & $5.457^{* * *}$ & 0.123 & 0.0274 & $-1.797^{* * *}$ \\
\hline & $(16.81)$ & $(19.21)$ & $(0.64)$ & $(0.17)$ & $(-12.06)$ \\
\hline \multirow[t]{2}{*}{ Experience } & 0.703 & $-12.64^{* * *}$ & $-9.258^{* * * *}$ & $-12.06^{* * *}$ & $3.189^{* * *}$ \\
\hline & $(1.12)$ & $(-10.75)$ & $(-12.26)$ & $(-19.10)$ & $(5.26)$ \\
\hline \multirow[t]{2}{*}{ Hours worked (week) } & $-5.890^{* * * *}$ & $-6.588^{* * *}$ & $21.18^{* * *}$ & $18.64^{* * * *}$ & $1.425^{*}$ \\
\hline & $(-7.14)$ & $(-5.74)$ & $(13.70)$ & $(17.96)$ & (1.67) \\
\hline \multirow[t]{2}{*}{ Income (month, yuan) } & $456.4^{* *}$ & $1069.9^{* * * *}$ & $-444.9^{* * *}$ & -222.4 & $-531.7^{* * * *}$ \\
\hline & $(2.39)$ & $(4.76)$ & $(-2.36)$ & $(-1.20)$ & $(-2.89)$ \\
\hline \multicolumn{6}{|l|}{ Job type } \\
\hline \multirow[t]{2}{*}{ Permanent } & $0.231^{* * *}$ & $0.376^{* * * *}$ & $-0.223^{* * * *}$ & $-0.193^{* * *}$ & \\
\hline & $(5.26)$ & $(7.46)$ & $(-4.63)$ & $(-4.35)$ & \\
\hline \multirow[t]{2}{*}{ Temporary } & $-0.153^{* * * *}$ & $-0.258^{* * * *}$ & -0.0337 & -0.0537 & \\
\hline & $(-3.71)$ & $(-5.57)$ & $(-0.73)$ & $(-1.28)$ & \\
\hline \multirow[t]{2}{*}{ Self-employed } & $-0.0775^{* *}$ & $-0.118^{* * *}$ & $0.257^{* * * *}$ & $0.247^{* * *}$ & \\
\hline & $(-2.47)$ & $(-3.42)$ & $(6.58)$ & $(7.46)$ & \\
\hline Obs. & 5192 & 786 & 1255 & 2888 & 14844 \\
\hline $\begin{array}{l}\text { Notes: The columns in th } \\
\text { previous table; therefore, } \\
\text { is land expropriated indiv } \\
<0.05,{ }^{* * *} p<0.01 \\
\text { Source. RUMiC }\end{array}$ & $\begin{array}{l}\text { le are the results } \\
\text { ample sizes corres } \\
\text { s in rural or urban }\end{array}$ & $\begin{array}{l}\text { t-tests of differ } \\
\text { o the sum of sal } \\
s \text { in each colum }\end{array}$ & $\begin{array}{l}\text { ween colum } \\
\text { of column } \\
\text { male spouse }\end{array}$ & $\begin{array}{l}\text { id columns (1)-(5) } \\
\text { columns (1)-(5) res } \\
\text { atistics are in paren }\end{array}$ & $\begin{array}{l}\text { ectively from th } \\
\text { ively. Base groul } \\
\text { es. }{ }^{*} p<0.10,{ }^{* *}\end{array}$ \\
\hline
\end{tabular}


Table 6 Summary Statistics across Different Groups (children)

\begin{tabular}{|c|c|c|c|c|c|c|}
\hline & \multicolumn{2}{|l|}{ Treated group } & \multicolumn{3}{|c|}{ Control groups } & \multirow[b]{3}{*}{ Rural stayers } \\
\hline & (0) & (1) & (2) & (3) & (4) & \\
\hline & $\begin{array}{c}\text { Expropriated } \\
\text { (urban + rural) }\end{array}$ & $\begin{array}{l}\text { Urban hukou } \\
\text { non-changers }\end{array}$ & $\begin{array}{l}\text { High education } \\
\text { hukou changers }\end{array}$ & $\begin{array}{c}\text { Migrants from } \\
\text { close-by }\end{array}$ & $\begin{array}{c}\text { Migrants from } \\
\text { far away }\end{array}$ & \\
\hline \multirow[t]{2}{*}{ Age } & 15.59 & 15.40 & 16.94 & 14.88 & 15.0 & 16.21 \\
\hline & $(3.186)$ & (3.171) & $(3.523)$ & $(3.181)$ & $(3.135)$ & $(2.942)$ \\
\hline \multirow[t]{2}{*}{ Male } & 0.480 & 0.534 & 0.722 & 0.517 & 0.573 & 0.506 \\
\hline & $(0.501)$ & $(0.499)$ & $(0.461)$ & $(0.501)$ & $(0.495)$ & $(0.500)$ \\
\hline \multirow[t]{2}{*}{ Sibling } & 1.540 & 1.101 & 1.118 & 1.781 & 1.853 & 1.767 \\
\hline & $(0.641)$ & $(0.313)$ & $(0.332)$ & $(0.731)$ & $(0.675)$ & $(0.679)$ \\
\hline \multirow[t]{2}{*}{ Disable } & 0.007 & 0.008 & 0 & 0.006 & 0.021 & 0.021 \\
\hline & $(0.082)$ & $(0.091)$ & (0) & $(0.075)$ & $(0.145)$ & $(0.142)$ \\
\hline \multirow[t]{2}{*}{ Education (years) } & 8.900 & 12.36 & 12 & 10.08 & 9.387 & 8.842 \\
\hline & (3.107) & (3.249) & (0) & $(2.371)$ & (1.651) & (1.886) \\
\hline \multirow[t]{2}{*}{ Father's education (years) } & 8.627 & 11.73 & 9.333 & 8.244 & 7.519 & 7.711 \\
\hline & $(3.127)$ & $(3.548)$ & $(3.087)$ & $(2.884)$ & $(2.745)$ & $(2.431)$ \\
\hline \multirow[t]{2}{*}{ Mother's education (years) } & 8.113 & 10.41 & 8.333 & 6.550 & 6.513 & 6.602 \\
\hline & $(3.114)$ & $(4.589)$ & $(4.446)$ & $(3.630)$ & $(3.499)$ & $(2.863)$ \\
\hline \multirow[t]{2}{*}{ Father's log wage } & 2.092 & 2.469 & 2.114 & 1.776 & 1.811 & 1.911 \\
\hline & $(0.542)$ & $(0.816)$ & $(0.627)$ & $(0.722)$ & $(0.734)$ & $(0.690)$ \\
\hline \multirow[t]{2}{*}{ Mother's log wage } & 1.996 & 2.351 & 2.002 & 1.596 & 1.631 & 1.616 \\
\hline & $(0.723)$ & $(0.775)$ & $(0.777)$ & $(0.728)$ & $(0.609)$ & $(0.684)$ \\
\hline Obs. & 150 & 1081 & 18 & 180 & 468 & 2126 \\
\hline
\end{tabular}

Notes: The summary statistics for children are limited to individuals of age 10-20 at the time of survey. The treated group consist of respondents who changed their hukou status to urban following expropriation.

Source: RUMiC (2008-2009). 
Table 7 T-test of Mean Differences (children)

\begin{tabular}{lccccc}
\hline & $\begin{array}{c}(1) \\
\text { Urban hukou } \\
\text { non-changers }\end{array}$ & $\begin{array}{c}(2) \\
\text { High education } \\
\text { hukou changers }\end{array}$ & $\begin{array}{c}(3) \\
\text { Migrants from } \\
\text { close-by }\end{array}$ & $\begin{array}{c}(4) \\
\text { Migrants from } \\
\text { far away }\end{array}$ & $\begin{array}{c}(5) \\
\text { Rural stayers }\end{array}$ \\
\hline Age & -0.186 & 1.358 & $-0.709^{* *}$ & $-0.591^{* *}$ & $0.625^{* *}$ \\
& $(-0.67)$ & $(1.56)$ & $(-2.01)$ & $(-1.98)$ & $(2.33)$ \\
Male & 0.0538 & $0.242^{* * *}$ & 0.0367 & $0.0926^{* *}$ & 0.0261 \\
& $(1.23)$ & $(2.09)$ & $(0.66)$ & $(1.98)$ & $(0.62)$ \\
Sibling & $-0.439^{* * *}$ & $-0.422^{* * * *}$ & $0.241^{* * *}$ & $0.313^{* * *}$ & $0.227^{* * *}$ \\
& $(-8.25)$ & $(-4.40)$ & $(3.18)$ & $(5.13)$ & $(4.17)$ \\
Disable & 0.00167 & -0.00667 & -0.00111 & 0.0147 & $0.0140^{*}$ \\
& $(0.23)$ & $(-1.00)$ & $(-0.13)$ & $(1.56)$ & $(1.91)$ \\
Education (years) & $3.457^{* *}$ & $3.100^{* *}$ & 1.183 & 0.487 & -0.0578 \\
& $(2.64)$ & $(3.15)$ & $(1.12)$ & $(0.49)$ & $(-0.06)$ \\
Father's education (years) & $3.107^{* * *}$ & 0.707 & -0.382 & $-1.107^{* * *}$ & $-0.916^{* * *}$ \\
& $(11.21)$ & $(0.92)$ & $(-1.15)$ & $(-3.88)$ & $(-3.51)$ \\
Mother's education (years) & $2.297^{* * *}$ & 0.220 & $-1.563^{* * *}$ & $-1.6011^{* * *}$ & $-1.511^{* * *}$ \\
& $(7.92)$ & $(0.20)$ & $(-4.21)$ & $(-5.31)$ & $(-5.77)$ \\
Father's log wage & $0.377^{* * *}$ & 0.0222 & $-0.316^{* * *}$ & $-0.281^{* * *}$ & $-0.181^{* * *}$ \\
& $(6.85)$ & $(0.13)$ & $(-4.25)$ & $(-4.74)$ & $(-3.47)$ \\
Mother's log wage & $0.355^{* * *}$ & 0.00644 & $-0.400^{* * *}$ & $-0.365^{* * *}$ & $-0.380^{* * *}$ \\
& $(4.93)$ & $(0.03)$ & $(-3.85)$ & $(-4.85)$ & $(-5.26)$ \\
\hline Obs. & 1231 & 168 & 330 & 618 & 2276 \\
\hline
\end{tabular}

Notes: The columns in this table are the results of the t-tests of differences between column (0) and columns (1)-(5) respectively from the previous table; therefore, the sample sizes correspond to the sum of sample sizes of column (0) and columns (1)-(5) respectively. Base group is land expropriated families in rural or urban surveys in each column (only children). T-statistics are in parentheses. ${ }^{*} p<0.10,{ }^{* *} p<0.05,{ }^{* * * *} p$ $<0.01$

Source: RUMiC (2008-2009). 
Table 8 Log Wage Regressions (male household heads)

Comparison groups

\begin{tabular}{|c|c|c|c|c|c|}
\hline & $\begin{array}{l}\text { Urban hukou } \\
\text { non-changers }\end{array}$ & $\begin{array}{l}\text { High education } \\
\text { hukou changers }\end{array}$ & $\begin{array}{l}\text { Migrants from } \\
\text { close-by }\end{array}$ & $\begin{array}{l}\text { Migrants from } \\
\text { far away }\end{array}$ & Rural stayers \\
\hline Expropriated & $\begin{array}{c}-0.144 * * \\
(0.063)\end{array}$ & $\begin{array}{c}-0.65 * * * \\
(0.113)\end{array}$ & $\begin{array}{c}0.165^{* *} \\
(0.081)\end{array}$ & $\begin{array}{c}0.349 * * * \\
(0.060)\end{array}$ & $\begin{array}{c}0.157^{* *} \\
(0.066)\end{array}$ \\
\hline Education (years) & $\begin{array}{c}0.070 * * * \\
(0.006)\end{array}$ & $\begin{array}{c}0.061 * * * \\
(0.018)\end{array}$ & $\begin{array}{c}0.052 * * * \\
(0.009)\end{array}$ & $\begin{array}{c}0.044 * * * \\
(0.005)\end{array}$ & $\begin{array}{c}0.002 \\
(0.007)\end{array}$ \\
\hline Experience & $\begin{array}{c}0.011 \\
(0.007)\end{array}$ & $\begin{array}{c}0.054 * * * \\
(0.020)\end{array}$ & $\begin{array}{c}0.030 * * * \\
(0.008)\end{array}$ & $\begin{array}{c}0.015 * * * \\
(0.004)\end{array}$ & $\begin{array}{c}0.026 * * \\
(0.012)\end{array}$ \\
\hline Experience squared & $\begin{array}{c}-0.000 * * \\
(0.000)\end{array}$ & $\begin{array}{c}-0.001 * * \\
(0.000)\end{array}$ & $\begin{array}{c}-0.001 * * * \\
(0.000)\end{array}$ & $\begin{array}{c}-0.000 * * * \\
(0.000)\end{array}$ & $\begin{array}{c}-0.001 * * * \\
(0.000)\end{array}$ \\
\hline Permanent job & & & Reference category & & \\
\hline Short-term/temporary job & $\begin{array}{c}-0.577 * * * \\
(0.039)\end{array}$ & $\begin{array}{l}-0.052 \\
(0.142)\end{array}$ & $\begin{array}{c}-0.069 * \\
(0.041)\end{array}$ & $\begin{array}{c}-0.097 * * * \\
(0.019)\end{array}$ & \\
\hline Self-employed & $\begin{array}{c}-0.137 * * * \\
(0.062)\end{array}$ & $\begin{array}{l}-0.039 \\
(0.184)\end{array}$ & $\begin{array}{c}0.020 \\
(0.056)\end{array}$ & $\begin{array}{c}0.066^{* *} \\
(0.031)\end{array}$ & \\
\hline Disable & $\begin{array}{c}-0.199 * * * \\
(0.075)\end{array}$ & $\begin{array}{l}-0.241 \\
(0.219)\end{array}$ & $\begin{array}{l}-0.180^{*} \\
(0.099)\end{array}$ & $\begin{array}{l}-0.038 \\
(0.066)\end{array}$ & $\begin{array}{c}-0.205 * * \\
(0.094)\end{array}$ \\
\hline Children & $\begin{array}{c}0.002 \\
(0.042)\end{array}$ & $\begin{array}{l}-0.048 \\
(0.082)\end{array}$ & $\begin{array}{l}-0.045 \\
(0.039)\end{array}$ & $\begin{array}{l}-0.023 \\
(0.019)\end{array}$ & $\begin{array}{c}-0.057 * * * \\
(0.022)\end{array}$ \\
\hline Married & $\begin{array}{c}0.379 * * \\
(0.155)\end{array}$ & $\begin{array}{c}0.134 \\
(0.294)\end{array}$ & $\begin{array}{c}0.063 \\
(0.057)\end{array}$ & $\begin{array}{c}0.170 * * * \\
(0.031)\end{array}$ & $\begin{array}{c}0.114 \\
(0.177)\end{array}$ \\
\hline Constant & $\begin{array}{c}1.097 * * * \\
(0.204)\end{array}$ & $\begin{array}{c}0.99 * \\
(0.536)\end{array}$ & $\begin{array}{c}0.726 * * * \\
(0.154)\end{array}$ & $\begin{array}{c}1.115 * * * \\
(0.070)\end{array}$ & $\begin{array}{c}1.474 * * * \\
(0.287)\end{array}$ \\
\hline Province effects & Yes & Yes & Yes & Yes & Yes \\
\hline Adjusted R2 & 0.314 & 0.416 & 0.296 & 0.157 & 0.069 \\
\hline Obs & 3266 & 390 & 1,008 & 3,953 & 2882 \\
\hline
\end{tabular}

Notes: Models are estimated by OLS. Standard errors are clustered at individual level and in parenthesis. Conventional significance notation is used: * $\mathrm{p}<.10, * * \mathrm{p}<.05, * * * \mathrm{p}<.01$.

Source: RUMiC (2008-2009). 
Table 9 Log Wage Regressions (female spouses)

\begin{tabular}{|c|c|c|c|c|c|}
\hline & \multicolumn{5}{|c|}{ Comparison groups } \\
\hline & $\begin{array}{l}\text { Urban hukou } \\
\text { non-changers }\end{array}$ & $\begin{array}{l}\text { High education } \\
\text { hukou changers }\end{array}$ & $\begin{array}{c}\text { Migrants from } \\
\text { close-by }\end{array}$ & $\begin{array}{c}\text { Migrants from } \\
\text { far away }\end{array}$ & Rural stayers \\
\hline Expropriated & $\begin{array}{l}-0.130 * \\
(0.068)\end{array}$ & $\begin{array}{c}-0.510^{* * * *} \\
(0.116)\end{array}$ & $\begin{array}{l}-0.004 \\
(0.087)\end{array}$ & $\begin{array}{c}0.037 \\
(0.113)\end{array}$ & $\begin{array}{c}0.232 * * * \\
(0.067)\end{array}$ \\
\hline Education (years) & $\begin{array}{c}0.071 * * * \\
(0.007)\end{array}$ & $\begin{array}{c}0.051 * * * \\
(0.018)\end{array}$ & $\begin{array}{c}0.035 * * \\
(0.014)\end{array}$ & $\begin{array}{l}0.039 * * \\
(0.019)\end{array}$ & $\begin{array}{c}0.029 * * * \\
(0.011)\end{array}$ \\
\hline Experience & $\begin{array}{l}-0.000 \\
(0.009)\end{array}$ & $\begin{array}{c}0.014 \\
(0.019)\end{array}$ & $\begin{array}{c}0.012 \\
(0.018)\end{array}$ & $\begin{array}{l}-0.005 \\
(0.020)\end{array}$ & $\begin{array}{c}0.014 \\
(0.013)\end{array}$ \\
\hline Experience squared & $\begin{array}{l}-0.000 \\
(0.000)\end{array}$ & $\begin{array}{l}-0.000 \\
(0.000)\end{array}$ & $\begin{array}{l}-0.000 \\
(0.000)\end{array}$ & $\begin{array}{l}-0.000 \\
(0.000)\end{array}$ & $\begin{array}{c}-0.000 * * \\
(0.000)\end{array}$ \\
\hline Permanent job & & & erence category & & \\
\hline Short-term/temporary job & $\begin{array}{c}-0.460 * * * \\
(0.035)\end{array}$ & $\begin{array}{l}-0.179 \\
(0.143)\end{array}$ & $\begin{array}{c}-0.177 * * \\
(0.083)\end{array}$ & $\begin{array}{l}-0.182 * \\
(0.094)\end{array}$ & \\
\hline Self-employed & $\begin{array}{c}-0.306 * * * \\
(0.084)\end{array}$ & $\begin{array}{c}0.140 \\
(0.258)\end{array}$ & $\begin{array}{c}0.096 \\
(0.154)\end{array}$ & $\begin{array}{c}0.150 \\
(0.164)\end{array}$ & \\
\hline Disable & $\begin{array}{c}0.061 \\
(0.143)\end{array}$ & $\begin{array}{c}0.167 \\
(0.367)\end{array}$ & $\begin{array}{l}0.523 * * \\
(0.219)\end{array}$ & $\begin{array}{c}0.864 * * * \\
(0.192)\end{array}$ & $\begin{array}{c}0.066 \\
(0.143)\end{array}$ \\
\hline Children & $\begin{array}{c}0.009 \\
(0.044)\end{array}$ & $\begin{array}{c}0.001 \\
(0.079)\end{array}$ & $\begin{array}{l}-0.044 \\
(0.062)\end{array}$ & $\begin{array}{l}-0.008 \\
(0.090)\end{array}$ & $\begin{array}{l}-0.040 \\
(0.031)\end{array}$ \\
\hline Married & $\begin{array}{c}-0.276^{* * *} \\
(0.041)\end{array}$ & & & & $\begin{array}{l}-0.068 \\
(0.429)\end{array}$ \\
\hline Constant & $\begin{array}{c}1.519 * * * \\
(0.176)\end{array}$ & $\begin{array}{l}1.38^{* * *} \\
(0.408)\end{array}$ & $\begin{array}{c}1.447 * * * \\
(0.385)\end{array}$ & $\begin{array}{l}1.188^{* *} \\
(0.496)\end{array}$ & $\begin{array}{c}1.339 * * * \\
(0.494)\end{array}$ \\
\hline Province effects & Yes & Yes & Yes & Yes & Yes \\
\hline Adjusted R2 & 0.312 & 0.409 & 0268 & 0.221 & 0.061 \\
\hline Obs & 2260 & 272 & 234 & 234 & 1437 \\
\hline
\end{tabular}

Notes: Models are estimated by OLS. Standard errors are clustered at individual level and in parenthesis. Conventional significance notation is used: * $\mathrm{p}<.10, * * \mathrm{p}<.05, * * * \mathrm{p}<.01$.

Source: RUMiC (2008-2009). 
Table 10 Job Types

\begin{tabular}{|c|c|c|c|c|c|c|}
\hline & \multicolumn{3}{|c|}{ Household heads } & \multicolumn{3}{|c|}{ Spouses } \\
\hline & $\begin{array}{l}\text { Expropriated } \\
\text { vs. Urban } \\
\text { hukou } \\
\text { non-changers }\end{array}$ & $\begin{array}{l}\text { Expropriated } \\
\text { vs. Migrants } \\
\text { from close-by }\end{array}$ & $\begin{array}{l}\text { Expropriated } \\
\text { vs. Migrants } \\
\text { from far away }\end{array}$ & $\begin{array}{c}\text { Expropriated } \\
\text { vs. Urban } \\
\text { hukou } \\
\text { non-changers } \\
\end{array}$ & $\begin{array}{l}\text { Expropriated } \\
\text { vs. Migrants } \\
\text { from close-by }\end{array}$ & $\begin{array}{l}\text { Expropriated } \\
\text { vs. Migrants } \\
\text { from far away }\end{array}$ \\
\hline \multicolumn{7}{|l|}{ Job type } \\
\hline Permanent & & Base group & & & Base group & \\
\hline Temporary & $1.680 * *$ & $0.446 * * *$ & $0.676^{*}$ & $1.534 *$ & 0.820 & $0.464 *$ \\
\hline Self-employed & 0.792 & $0.231 * * *$ & $0.317 * * *$ & 1.517 & $0.487 *$ & $0.204 * * *$ \\
\hline Controls & Yes & Yes & Yes & Yes & Yes & Yes \\
\hline Province effects & Yes & Yes & Yes & Yes & Yes & Yes \\
\hline Time effects & Yes & Yes & Yes & Yes & Yes & Yes \\
\hline Obs. & 3293 & 1012 & 3976 & 2277 & 235 & 237 \\
\hline Pseudo-R2 & 0.072 & 0.128 & 0.109 & 0.084 & 0.115 & 0.175 \\
\hline
\end{tabular}

Notes: Models are estimated by multinomial logit specification. The reported numbers are exponentiated coefficients and are interpreted as relative risk ratios of being in temporary or self-employed job (as opposed to a permanent job) of expropriated individuals compared to individuals in the respective reference group at each column. Control variables include education, experience and squared, children, disability and marital status. Conventional significance notation is used: * $\mathrm{p}<.10, * * \mathrm{p}<.05$, *** $\mathrm{p}<.01$.

Source: RUMiC (2008-2009). 
Table 11 Treatment effects (wage regressions): transmission channels

\begin{tabular}{|c|c|c|c|c|c|}
\hline & \multicolumn{5}{|c|}{ Comparison groups } \\
\hline & $\begin{array}{l}\text { Urban hukou } \\
\text { non-changers }\end{array}$ & $\begin{array}{l}\text { High education } \\
\text { hukou changers }\end{array}$ & $\begin{array}{l}\text { Migrants from } \\
\text { close-by }\end{array}$ & $\begin{array}{l}\text { Migrants from } \\
\text { far away }\end{array}$ & Rural stayers \\
\hline \multicolumn{6}{|l|}{ Age groups interactions } \\
\hline Age $<25$ & \multicolumn{5}{|c|}{ Reference category } \\
\hline \multirow[t]{2}{*}{ Age $<30$} & -0.189 & -0.371 & 0.044 & 0.239 & $0.802 * * *$ \\
\hline & $(0.207)$ & $(0.224)$ & $(0.125)$ & $(0.157)$ & $(0.182)$ \\
\hline \multirow[t]{2}{*}{ Age $<35$} & $-0.517 * * *$ & $-0.597 * *$ & -0.027 & 0.171 & $0.268 * *$ \\
\hline & $(0.119)$ & $(0.153)$ & $(0.135)$ & $(0.104)$ & $(0.134)$ \\
\hline \multirow[t]{2}{*}{ Age $<40$} & $-0.428 * * *$ & $-0.776 * * *$ & 0.003 & 0.116 & 0.094 \\
\hline & $(0.100)$ & $(0.130)$ & $(0.112)$ & $(0.093)$ & $(0.095)$ \\
\hline \multirow[t]{2}{*}{ Age $<45$} & $-0.268 * * *$ & $-0.662 * * *$ & 0.128 & $0.268 * * *$ & $0.182 * *$ \\
\hline & $(0.081)$ & $(0.118)$ & $(0.099)$ & $(0.076)$ & $(0.072)$ \\
\hline \multirow[t]{2}{*}{ Age $<50$} & $-0.204 * * *$ & $-0.637 * * *$ & 0.095 & $0.308 * * *$ & $0.162 * *$ \\
\hline & $(0.067)$ & $(0.114)$ & $(0.087)$ & $(0.065)$ & $(0.067)$ \\
\hline \multirow[t]{2}{*}{ Age $<55$} & $-0.168 * * *$ & $-0.673 * * *$ & $0.165 * *$ & $0.323 * * *$ & $0.164 * *$ \\
\hline & $(0.062)$ & $(0.118)$ & $(0.081)$ & $(0.059)$ & $(0.067)$ \\
\hline \multicolumn{6}{|l|}{ Ownership interactions } \\
\hline \multirow{3}{*}{$\begin{array}{r}\text { Private/Self-employed } \\
\text { SOE }\end{array}$} & \multicolumn{5}{|c|}{ Reference category } \\
\hline & $-0.257 * * *$ & $-0.631 * * *$ & 0.115 & $0.240 * * *$ & \\
\hline & $(0.087)$ & $(0.123)$ & $(0.104)$ & $(0.084)$ & \\
\hline \multirow[t]{2}{*}{ Foreign-owned } & -0.252 & $-0.744 * * *$ & 0.222 & 0.395 & \\
\hline & $(0.192)$ & $(0.250)$ & $(0.247)$ & $(0.251)$ & \\
\hline \multicolumn{6}{|l|}{ Job search interactions } \\
\hline Own/employer & & & Reference category & & \\
\hline \multirow[t]{2}{*}{ Government } & $-0.371 * * *$ & $-0.735 * * *$ & 0.047 & $0.294 * *$ & $0.377 * * *$ \\
\hline & $(0.096)$ & $(0.127)$ & $(0.120)$ & $(0.117)$ & $(0.111)$ \\
\hline \multirow[t]{2}{*}{ Network } & 0.045 & $-0.905 * * *$ & $0.198 * *$ & $0.383 * * *$ & 0.109 \\
\hline & $(0.095)$ & $(0.220)$ & $(0.094)$ & $(0.083)$ & $(0.076)$ \\
\hline \multirow[t]{2}{*}{ Other } & -0.148 & -0.344 & 0.177 & $0.310 *$ & 0.229 \\
\hline & $(0.168)$ & $(0.328)$ & $(0.164)$ & $(0.175)$ & $(0.181)$ \\
\hline
\end{tabular}

Notes: Models are estimated by OLS (male household heads only). Standard errors are clustered at individual level and in parenthesis. Other controls include education, experience and its squared, job type, disability status, number of children, and marital status. Conventional significance notation is used: * $\mathrm{p}<.10, * * \mathrm{p}<.05, * * * \mathrm{p}<.01$.

Source: RUMiC (2008-2009). 
Table 12 Children Education

\begin{tabular}{lccccc}
\multicolumn{5}{c}{ Comparison groups } \\
\hline & $\begin{array}{c}\text { Urban hukou } \\
\text { non-changers }\end{array}$ & $\begin{array}{c}\text { High education } \\
\text { hukou changers }\end{array}$ & $\begin{array}{c}\text { Migrants from } \\
\text { close-by }\end{array}$ & $\begin{array}{c}\text { Migrants from } \\
\text { far away }\end{array}$ & Rural stayers \\
\hline Expropriated & $0.339^{*}$ & 0.748 & $0.786^{* *}$ & $0.737^{* *}$ & $1.503^{* * *}$ \\
Age & $(0.199)$ & $(0.599)$ & $(0.308)$ & $(0.321)$ & $(0.362)$ \\
& $0.972^{* * *}$ & $0.812^{* * *}$ & $0.822^{* * *}$ & $0.651^{* * *}$ & $0.833^{* * *}$ \\
Male & $(0.017)$ & $(0.093)$ & $(0.069)$ & $(0.087)$ & $(0.076)$ \\
& -0.085 & 0.156 & 0.063 & $0.542^{* *}$ & -0.259 \\
Disability & $(0.089)$ & $(0.279)$ & $(0.292)$ & $(0.262)$ & $(0.308)$ \\
& -0.422 & $2.103^{*}$ & 0.743 & 0.142 & $0.787^{* *}$ \\
Sibling & $(0.355)$ & $(1.074)$ & $(0.547)$ & $(0.647)$ & $(0.375)$ \\
Father education (years) & -0.078 & 0.109 & -0.249 & -0.180 & -0.357 \\
Mother education (years) & $(0.132)$ & $(0.762)$ & $(0.376)$ & $(0.225)$ & $(0.255)$ \\
Father log wage & 0.030 & 0.078 & -0.066 & $0.153^{*}$ & $0.174^{*}$ \\
& $(0.023)$ & $(0.091)$ & $(0.072)$ & $(0.086)$ & $(0.093)$ \\
Mother log wage & $0.042^{* *}$ & -0.045 & 0.019 & $-0.127^{* *}$ & 0.003 \\
& $(0.020)$ & $(0.079)$ & $(0.075)$ & $(0.057)$ & $(0.082)$ \\
Province effects & -0.038 & -0.302 & -0.094 & 0.007 & -0.086 \\
Adjusted R2 & $(0.064)$ & $(0.372)$ & $(0.264)$ & $(0.301)$ & $(0.305)$ \\
Obs & -0.114 & -0.119 & 0.119 & -0.058 & -0.142
\end{tabular}

Notes: Models are estimated by OLS. Standard errors are clustered at individual level and in parenthesis. Conventional significance notation is used: $* \mathrm{p}<.10, * * \mathrm{p}<.05, * * * \mathrm{p}<.01$.

Source: RUMiC (2008-2009). 